\title{
EFFECT OF MICROFINANCE BANKS ON THE GROWTH OF SELECTED SMALL AND MEDIUM SCALE ENTERPRISES IN MAKURDI METROPOLIS, BENUE STATE
}

\author{
Adamu Garba ${ }^{1 *}$ \\ *l Department of Business Administration, Nasarawa State University, Keffi, Nasarawa State
}

*Corresponding Author: -

\begin{abstract}
: -
This study examined the effect of microfinance banks on the growth of selected small and medium scale enterprises in Makurdi Metropolis, Benue State.The study was anchored on Pecking Order theory. The researcher used both primary and secondary sources from a population of 960 and a sample of 282 respondents obtained by the use of a structured questionnaire. The data collected were analyzed using descriptive statistics such as frequency, simple percentage and the relationship between the variables of the model was tested using multiple linear regression analysis. The result of the regression analysis indicates that a positive relationship exist between Credit by Microfinance (CMF) Job Creation (JOC) of selected SMEs in Makurdi Metropolis and the relationship is statistically significant $(p<0.05)$. A positive relationship exist between Credit by Microfinance and Business Expansion (BEX) of selected SMEs in Makurdi Metropolis and the relationship is statistically significant ( $p<0.05)$. A negative relationship exist between Savings Mobilization and the Growth of Small and Job Creation (JOC) of selected SMEs in Makurdi Metropolis and the relationship is not statistically significant ( $p>0.05)$. A positive relationship exist between Savings Mobilization (SMB) and Business Expansion (BEX) of selected SMEs in Makurdi Metropolis and the relationship is statistically significant $(p<0.05)$. It was concluded that micro finance does enhance the job creation and expansion capacity of small business in Nigeria. It was recommended among others that microfinance bank should adopt similar strategies adopted by deposit money banks in deposit mobilization because it is by so doing that they will be able to grant quality loans to entrepreneurs which will lead to job creation in the economy.
\end{abstract}

Keyword: Microfinance, Bank, Growth, SMEs, Benue, Nigeria

\section{(우 $\circledast$ (1)}




\subsection{INTRODUCTION}

The Small and Medium Scale Enterprises is considered as the engine that drives the economy of any nation as it provides opportunities for the countless millions of unemployed people to productively engaged in one venture or the other. The contribution of Small and Medium Scale Enterprises to employment generation, improvement in the standard of the life of the people has been globally acknowledged. As beautiful as this role of Small and Medium Scale Enterprises is in bringing about the much-needed improvement in the society. majority of the Small and Medium Scale Enterprises (SMEs) in Nigeria are still at a low level of development, especially in terms of number of jobs, wealth and value creation. This is because $65 \%$ of the active population, who are majorly entrepreneurs, remain unserved by the formal financial institutions (Abiola and Salami, 2011).

The Small and Medium Enterprises (SMEs) represent about 87 per cent of all firms operating in Nigeria (USAID, 2015). Nonfarm micro, small and medium enterprises account for over 25 per cent of total employment and 20 percent of the GDP (SMEDAN, 2017) compared to the cases of countries like Indonesia, Thailand and India where Micro, Small and Medium Enterprises (MSMEs) contribute almost 40 percent of the GDP. Whilst SMEs are an important part of the business landscape in any country, they are faced with significant challenges that inhibit their ability to function and contribute optimally to the economic development of many African countries. The position in Nigeria is not different from this generalized position. Realizing the importance of small businesses as the engine of growth in the Nigerian economy, the Government took some steps towards addressing the conditions that hinder their growth and survival (Aderibigbe, 2001).

A micro-enterprise (or microenterprise) is generally defined as a small business employing nine people of fewer, and having a turnover of less than a certain amount (e.g. 2,000,000 Euros 3,000,000) the term microenterprise have the same meaning, though traditionally when referring to a small business financed by microcredit the term microenterprise is often used. Similarly, when referring to small usually legal business that is not financed by micro credit, the term micro business (or micro-business is often used). Internationally, most micro enterprises are family business employing one or two persons. Most micro enterprises owners are primarily interested in earning a living to support themselves and their families. They only grow the business when something in their lives changes and they need to generate a larger income. Micro enterprises are said to add value to a country's economy by creating jobs, enhancing income, strengthening purchasing power, lowering cost and adding business convenience (Acha, 2012).

The contribution of micro enterprise businesses to economic growth has been recognized worldwide, they are very necessary for economic development in developing countries like Nigeria. The importance of micro enterprises business cannot be over emphasized, as they contribute to employment generation, income equality, production of goods and services as well as improved standard of living and rapid industrialization. Micro enterprises businesses can foster economic and social development in Nigeria as they are the back bone of the Nigeria economy (Bello, 2015).

In Nigeria, one of the great challenges microenterprises businesses faces is inaccessibility to funds because the commercial banks traditionally lend medium and large enterprises which are judged to be credit worthy. They avoid doing business with the "poor" and their micro enterprises because the associated cost and risk are considered to be relatively high. Even where loan facilities are readily obtainable, they may not be able to muster the needed collateral to access it. This circumstance has led to many of the micro enterprises business operators shutting down their business resulting to loss of many skilled, semi-skilled and unskilled jobs all over the country. Micro finance banks have therefore become the main source of funding for microenterprises business in Nigeria and other developing countries (Ehigiamusoe, 2016).

\section{Statement of the Problem}

The introduction of microfinance banks is a laudable one because it replaced the ailing community banks created by former Military Head of State General Ibrahim Babangida. This commendable project has been hijacked by money bags and the concept misapplied because of the Central Bank of Nigeria (CBN) directive that every Microfinance Bank should have not less than 25 million naira as a minimum reserve, while at the same time ordering the Nigerian Deposit Insurance Commission (NDIC) to insure each depositor for a maximum of 100 thousand naira regardless of the money invested. The implications of these requirements are that the microfinance banks or industries are out of reach of the very poor people it is meant to serve.

The microfinance institutions available in the country are not able to adequately address the gap in terms of credit, savings and other financial services. As reported by the CBN, the share of micro credit as a percentage of total credit was $0.9 \%$, while its contribution to GDP was a mere $0.2 \%$ (CBN, 2015). The CBN, in 2015 identified the unwillingness of conventional banks to support micro-enterprises, paucity of loanable funds, absence of support institutions in the sector, as well as weak institutional and managerial capacity of existing microfinance institutions among other reasons as the major reasons for the failure of past microfinance initiatives in the country (Central Bank of Nigeria, 2005).

Despite the potential importance of SMEs in any economy, high mortality rate among established SMEs is a matter of major concern in developing economies. International Finance Corporation (IFC) reported in 2002 that only 2 out of every 10 newly established businesses survive up to the fifth year in Nigeria. The report was corroborated by Small and Medium Enterprise Development Agency of Nigeria (SMEDAN) that only 15\% of newly established businesses survive the first five years in Nigeria. This is a pointer to the fact that there is a problem. The indispensable role of finance to the growth and survival of SMEs and the adoption of microfinance as the main source of financing SMEs in Nigeria therefore makes it imperative to study the extent to which microfinance can enhance small business growth and survival. The impact of micro-financing majorly should be seen in the multiplication of SMEs across Nigeria. The growth and survival of these SMEs should reflect in employment generation, engagement of available local resources, local technology utilization, 
improved standard of living and growing gross domestic product (GDP). It is in the light of the forgoing that this study evaluates the effect of microfinance banks and the growth of selected small and medium scale enterprises in Makurdi Benue State.

The main objective of this study is to determine Effect of Microfinance Banks on the Growth of selected Small and Medium Scale Enterprises in Makurdi metropolis, Benue State. The specific objectives however are to: Determine the effect of credits by microfinance banks on job creation by selected SMEs in Makurdi Metropolis. Examine the effect of credit by microfinance on business expansion of selected SMEs in Makurdi Metropolis. Determine the effect of savings mobilization by microfinance job creation by selected SMEs in Makurdi Metropolis and Examine the effect of savings mobilization by microfinance on business expansion of selected SMEs in Makurdi Metropolis.

\subsection{LITERATURE REVIEW \\ Theoretical framework \\ Pecking Order Theory}

Another financing theory that is very familiar with the operations of the small business is the pecking order theory, proposed by Myers (1984). It sheds light on the incentives that drive SMEs capital structure decisions. This theory proposes that firms prefer to use internal sources of capital for operation and will only resort to external sources if internal sources are inadequate. This theory has been found to be relevant to the financing of SMEs. Most SMEs start with internal financing before looking for external sources. Older firms, by definition, have had more opportunities to accumulate retained earnings than younger companies and thus more funds are available to finance operational growth. Pecking order theory suggests that those funds should be used before external capital sources are tapped. Holmes and Kent (1991) found that small businesses experience a more intense version of pecking order in their decisions because access to appropriate external sources of capital is limited. It has been noted that small businesses differ in their capital structure but their intense reliance on pecking order is only one of the variables that make small businesses financing decision unique. Small businesses' rely on private capital markets, while larger firms are financed through public market. Information on small businesses is much less readily available than information on larger firms which can be picked up in the annual reports. Small businesses reliance on private markets limits the types of financing that they can receive; most small businesses rely on commercial banks and finance companies to provide capital (Berger and Udell, 1998). In most cases, the cost of capital for small businesses is usually higher than it is for larger firms. The size of the loan and lack of information on the quality of operation of the small firms force lenders to protect their investment by demanding higher rates of return, which come in the form of high interest rate and high cost of capital for the small firm. In an attempt to avoid higher cost of capital, smaller firms are then forced to use more short-term debt, which carries lower costs but raises the firm's risk (Chittenden et al., 1996). When loaning to small businesses, most financial institutions require the owners of the small businesses to personally guarantee the loan. These personal guarantees allow the institution recourse against the personal wealth of the small business's owner in the event of default (Berger and Udell, 1998). These restrictions on the type of finance available to SMEs coupled with the small firm's insistence on first using internal sources of capital (Holmes and Kent, 1991), creates a unique structure for small business. Romano, et al., (2001) describe the situation as "a complex array of factors that influence small -to - medium size enterprises (SME) owner-manager's financing decisions'”. This is supported by Hall et al. (2010) who found that firm's size is positively related to long-term debt and negatively related to short-term debt. In further support, Chittenden et al. (1996) suggest that a firm's size is correlated with the firm's reliance on pecking order theory in capital structure decisions. Thus, smaller firms are more likely to rely on internal funds. Romano et al. (2001) found a significant relationship between the size of the firm and the use of debt. Again, these results are consistent with pecking order theory and the Berger and Udell (1998) theory.

Availability of information is another factor that limits the financing ability of the small firm. Small firms often do not have audited financial statements. Larger firms, on the other hand, must disclose a large amount of information about their financial standing on a systematic basis. As a result of this information void, the investor in small firms is unable to distinguish between highquality and low-quality companies and therefore raises the firm's cost of funding to compensate for risk. The investor will require a high rate of return in exchange for investing in a firm without all of the proper information. The investor requires this higher rate of return because the information is not available to establish the extent to which the small firm is likely to default. This actually limits small firms in accessing external fund (Wucinich, 2009).

\section{Conceptual Framework Concept of Microfinance}

The Central Bank of Nigeria (CBN, 2014) defines microfinance as the provision of financial services to the economically active poor and low income households. These services include credit, savings, micro-leasing, micro-insurance and payment transfer, to enable them to engage in income generating activities. The microfinance Policy defines the framework for the delivery of these financial services on sustainable basis to the Micro, Small and Medium Enterprises (MSMEs) through privately-owned Microfinance Banks (Ketu, 2008). Ojo (2009) defined microfinance as small scale financial services that are provided to rural/informal small scale operators for farming, fishing, trading, and building of houses and to engage in any other productive and distributive activities. Microfinance and micro financial institutions are intended to fill a definite gap in the finance market and the financial system respectively, to assist the financing requirements of some neglected groups who may be unable to obtain finance from the formal financial system. These neglected groups that constitute the target users of such microfinance are mainly in the informal sector of the economy and are predominantly engaged in small scale farming, commercial/trading and industrial activities.

Hannan (2018), describes microfinance as an amazingly simple approach that has been proved to empower very poor people around the world to pull them out of poverty. It is a financial system that relies on the traditional skills and 
entrepreneurial instincts of the active poor people, mostly women, using small loans (usually less than US\$200), other financial services, and support from local organizations called microfinance institutions (MFIs) to start, establish, sustain, or expand very small, self-supporting businesses. A key to microfinance is the recycling of loan. As each loan is repaidusually within six months to a year - the money is recycled as another loan, thus multiplying the value of each loan in defeating global poverty and changing lives and communities. He further explains that microcredit refers specifically to loans and the credit needs of clients, while microfinance covers a broader range of financial services that create a wider range of opportunities for success. Examples of these additional financial services include savings, insurance, housing loans and remittance transfers. The local MFI might also offer microfinance in addition to activities such as entrepreneurial and life skills training, and advice on topics like health and nutrition, sanitation, improving living conditions and the importance of educating children.

\section{Growth of Small and Medium Scale Enterprises}

The growth of the small and medium enterprises (SMEs) is an important field in the industrial organization theory. Growth of SMEs is the examination of the entry and exit of SMEs as a test to determine whether the transition is successful and whether the market mechanism has played its dominant role (Abdesselam et al., 2014). SMEs growth, survival and postentry performance is determined by entrepreneurs-specific characterize which include the perspective of the entrepreneurs' personal factors, financial strength and ownership type, their gender, age, professional background, educational attainment, and other characteristics which have impacts on growth indicators and fundamentals (EstevePérez and Mañez-Castillejo, 2008).

In line with (Abdesselam et al, 2014) growth of SMEs is ability of SMEs to penetrate into market or exit from the business which depend to a great extent on adequate funding and management process. The growth of SMEs is not optimistic around the world. According to previous researches, 68\% of all SMEs in the United States made their exit from business within 5 years, only $19 \%$ survived from 6 to 10 years, and merely $13 \%$ survived for more than 10 years (Lv, 2000). In Europe, only $65 \%$ of SMEs survived for more than 3 years, and $50 \%$ survived for more than 5 years.

Moreover, since the market competition performs the function of driving the inefficient enterprises out of the market, the examination of the entry and exit of SMEs in Nigeria could be viewed as a testing to determine whether the transition is successful and whether the market mechanism has played its dominant role in Nigeria (Abdesselam et al., 2014). There are abundant determinants of enterprise growth which are divided into personal/demographic, enterprise-specific, sectorspecific and other environmental levels (Brüderl et al. 2012).

It is evident from the literature that not all small businesses are growth oriented and for certain firms' growth is not a voluntary choice (Masurel and Montfort, 2016). An empirical study of SMEs growth pattern by Kolvereid and Bullvag (2016) concludes that growth intentions may be used to predict actual growth, that past intentions are related to later intentions, and that change in growth intentions are associated with changes in growth patterns.

Arbaurgh and Sexton (1996) provide empirical evidence that most new firms do not grow into large ones and that there is no relationship between the age of a firm and its size. Chaston and Mangles (2017) opine that there is no single strategy to firm growth. Hence, the probability of achieving growth is increased by avoiding excessive emphasis on single-strategy transformation initiatives, and by giving different capabilities priority depending upon the development stage of the firm. They identify three factors that can limit the growth of small business; namely ability, need and opportunity.

Kolveried (2016) concluded that small business entrepreneurs who want their firms to grow start their business in order to achieve just that. The process of mutual adjustment between proprietors and their employees was identified by Goffee and Scase (2015) as a major limiting factor of small business growth. Crises in small high tech firms is usually caused by poor financial records, weak general management, product competition, diversification and acquisition, changing capital demand, high overhead structure, manufacturing and operating problems, cancelation or delay of major contracts, poor marketing and price competition.

\section{Review of Related Empirical Studies}

Ojo (2009) investigated the impact of microfinance on entrepreneurial development of small scale enterprises that are craving for growth and development in a stiffened economy of Nigeria. The researcher used questionnaire as an instrument of primary data collection. The study centers on two broad variables; the dependent variable which is entrepreneurial development and the independent variable which is microfinance institutions. The researcher used three different hypotheses to formulate and tested various statistical tools such as chi-square test, analysis of variance and simple regression analysis. The study reveals that (i) there is a significant difference in the number of entrepreneurs who used microfinance institutions and those who do not use them; (ii) there is a significant effect of microfinance institutions activities in predicting entrepreneurial productivity; and (iii) that there is no significant effect of microfinance institutions activities in predicting entrepreneurial development. The study concludes that microfinance institutions world over and especially in Nigeria are identified to be one of the key players in the financial industry that have positively affected individuals, business organizations, other financial institutions, the government and the economy at large through the services they offer and the functions they perform in the economy.

The variables used in the study are considered relevant to this study and the use of survey design is in agreement with this study. However, the use of chi-square test as method of data analysis differs from this research which used regression for testing of hypotheses

Ediomo-Ubong and Iboro-Ekpo (2010) investigated micro-credit scheme and its impact on rural poverty, using of a lending scheme operated by a local NGO in Akwa Ibom State as a case study. Drawing upon qualitative data collected 
through in-depth personal and group interviews with beneficiaries of the scheme, the study examines the scope of micro credit programs for reducing poverty, the constraints facing credit schemes and how they may be addressed. The findings showed among others that micro-credit schemes present enormous potentials for enhancing income generation; improving household's living condition and reducing abject poverty in rural areas. Therefore, gendering credit programmes, integrating social collateral and shared liability principles, training beneficiaries on small business management and building the capacity of program staff as measures for improving efficiency were recommended. The shortcomings of this empirical review is that the population, sampling and sample for the study was not stated, the statistical method of data analysis was not equally stated. These anomalies will be corrected by the present study.

Babajide (2011) investigated the effects of micro-financing on Micro and Small Enterprises (MSEs) in South-west Nigeria. The study examined how micro-finance and non-financial micro-financing activities and features such as group membership, pre-loan training, cross guaranteeship, loan size, technical and managerial training, among others, impact on the survival, growth, productivity and performance of Micro and Small Enterprises in Southwest Nigeria. The validity and reliability of the instrument were measured using Cronbach's alpha which gave a result of 0.72 , while predictive form validity was 0.84 . Four hypotheses were raised and tested at 0.05 significant levels.

The findings revealed that micro finance and micro-financing enhance survival of Micro and Small Enterprises (MSEs) and sufficient for growth and expansion of such Micro and Small Enterprises. The result also revealed that microfinance has positive effects on productivity and performance of local entrepreneurs. The findings from the interview sessions revealed that micro financing is not effective and substantially being practiced in Nigeria as many MFBs grant more individual loans than group based loans, thereby increasing their running cost and putting their portfolio at risk.

This study is analogous, in that it investigated the effects of micro-financing on Micro and Small Enterprises (MSEs) in South-west Nigeria. However, the study was able to shows the scope which was in line with the current study but was unable provide recommendations to the findings.

Ngozi (2012) investigated Women Entrepreneurship and Development: The Role of Microfinance in Nigeria. The study specifically examined the extent to which programmes have resulted in women's economic, social, and political empowerment. The study also extrapolated the effects of microfinance on the mitigation of poverty. Finally, the study examined the policy implications of microcredit financing of women economic activities within the broad framework of gender stereotypical milieu of these enterprises. The propositions that are made in this study are (i) there a direct relationship between microcredit availability and economic development in Nigeria (ii) there is a direct relationship between microcredit and women empowerment in Nigeria (iii) the availability of microcredit facilitates income generating activities among people and contributes to their increased standard of living; (iv) that there is an association between micro financial institutions and the development of financial sustainability among Nigerian women; and (iv) that micro financial institutions are directly associated with women leadership development in Nigeria.

This study is similar, in that it examines microfinance programmes from the angle of government and non-government the extent it has integrated women in Nigeria. However, the study failed to state the statistical tool used, the method of data collection to arrive at it findings and also could not provide recommendations to the investigation. Therefore, our present study corrects this anomaly as we estimate to function with ordinary least square regression model, analysis of variance (ANOVA) to establish the difference between one variable and the other. This study would also proffer recommendation to the study.

Iganiga and Asemota (2008) examined the Nigerian unorganized rural financial institution and operations: A framework for improved rural credit schemes in a fragile environment using correlations. Empirical results shows that Traditional Savings and Credit Associations (TRASCAs) are prevalent in semi-urban and rural areas among semi-skilled and unskilled workers and traders, while Daily Saving Enterprises (DSEs) and Professional Money Lending Scheme (PMLs) strive in semi-urban and urban centers among artisans, traders and skilled workers. The performance analysis of these unorganized financial markets possibly reflects strong savings propensities and more robust lending activities.

This study is analogous, in that it examines Nigeria unorganized rural financial institution and operation. However, the study was able to shows the result of the findings, but failed to state the methodology used in carrying out this work and also could not provide recommendations to the investigation. Therefore, our present study modifies this anomaly as we estimate to function with ordinary least square regression model, analysis of variance (ANOVA) to establish the difference between one variable and the other. This study would also proffer recommendation to the study.

Sambe, Korna and Abaniyan (2013) in a study of the Effect of Microfinance Institutions on Socio-economic development in Nigeria. The study made use of randomly sampled 200 respondents as questionnaires. Chi-square was employed in the test of hypotheses. Dependency theory was used in analyzing the study. Findings showed that Informal Microfinance Institutions were more effective in improving job creation through the volumes of savings they mobilize from the various businesses in the rural area. These savings are loaned to entrepreneurs who use them or business expansion thus reducing poverty among members than non-members. Furthermore, the institutions guaranteed more access to credit than nonmembers and lastly, Informal Financial Institutions were effective in promoting investment among members as compared to non-members. 
This study, the effect of microfinance institution on socio economic development was wrongly estimated using chi-square instead of regression analysis thus leading to model misspecification and the findings from the study will be biased and misleading as chi-square is not used to estimate effect of an independent variable (s) on the dependent variable (s).

Ndugbu, Ojiegbe, Lawrence and Okere (2015) examined the relationship between bank and non-bank financial institutions and the development of the Nigerian economy. The data collected were analyzed using the E-views econometric software under the Ordinary Least Square (OLS) regression analysis. The study as confirmed by the result of the joint test revealed that the financial institutions play prominent role on the growth and development of the Nigerian economy. However, it was further revealed that individual contributions of the explanatory variables varied. For example, the Deposit Money Banks were revealed to have impacted very insignificantly to the growth and development of the Nigerian economy. This may not be unconnected with the unwholesome practices in the banking sector such as granting of loans/advances to "ghost" applicants, diversion of loans and advances granted, high incidence of moral hazards.

This study is similar to the current research, it examines the relationship between bank and non-bank financial institutions and the development of the Nigerian economy. However, the study used E-views econometric software while the current study utilizes Statistical Package for Social Sciences (SPSS) as a statistical software. The differences in the statistical software will have an impact in the final outcome of the study. It also failed to state the method of data collection and recommendations to the study. Thus, the present study amends this irregularity.

Idowu, Ambali and Otunaiya (2010) examined the effect of microfinance on piggery business in Osun State, Nigeria. The data collected were analyzed using descriptive statistics and Tobit regression. The study revealed that majority of the piggery farmers are still in their active age (66\% are below 50 years), married and educated (26\% had first degree). Also, majority of the farmers sourced for loan through cooperative societies and have stocking of pens as primary motive. The Tobit result revealed that level of education, years of experience in piggery farming and number of pigs had significant positive effect on fund security. Interest rate on loans obtained should be reduced while quality and quantities of input should increase. As a policy option, financial institutions and cooperative societies need to relax the transaction cost associated with loan procurement and more funds should be made available to piggery farmers at minimum cost to increase the output of the piggery industry. The findings of the study are relevant to the study but the scope of study covered by Idowu, Ambali and Otunaiya (2010) is different from this study.

The demerit of this empirical review is that policy recommendation was not made. The population and sample for the study was not explicitly stated. These made the empirical review defective.

Kpelai (2010) examined financing options and constraints to small business in Benue State North Central Nigeria. The objective of the study was to evaluate the sources of finance and factors that militate against small businesses accessibility to fund. The study utilized primary data which was collected through administration of two sets of questionnaires. Questionnaire one was administered on sample of 90 registered small businesses and questionnaire two on 34 credit institutions in Benue State. Two hypotheses were tested using the primary data and the statistical tools used were chisquare test of independence for hypothesis one and Pearson correlation for hypothesis two. Empirical findings suggest that small businesses in Benue State sourced their finances mainly through internal sources and that the small business borrower's collateral is still the major constraint faced by small business promoters in addressing institutional credits. Recommendations made include: establish framework for development of private equity markets, reintroduction of the mandatory $20 \%$ of total credit allocation to small businesses by Nigeria banks, sustained capacity building programmes for small business owners in Benue State among others. The findings of the study are relevant to the study but the scope of study covered by Kpelai (2010) is different from this study. Both Chi square and Pearson Correlation tests relationship and that is the weakness of this model as different statistical method would have been used.

\subsection{RESEARCH METHODOLOGY}

Survey research design was adopted for this study to examine the Effect of microfinance Banks on the Growth of Microscale Enterprises in Makurdi metropolis. The population of this study comprised of 960 micro-scale enterprises financed by microfinance banks in Makurdi metropolis. The data were obtained from credit units of five microfinance banks. These micro-scale enterprises include barbing and hair dressing salons, dress making, laundry services, restaurants and food processing, agriculture/ palm oil and carpentry/ craft workshop etc. This population framework was made up of male and female who were twenty years and above but not more than sixty-five years of age in Makurdi metropolis. Snow-ball sampling technique was then used to identify most of the respondents that have received microfinance banks' credits. The method adopted to determine the sample size for the study is "Taro Yamane's formula" and it was determined that 960 population gave a sample size of 282. Data was collected using questionnaire.

To ensure that the data gathering instrument being used will measure what it is supposed to measure and will do this in a consistent manner, the validity and reliability of the instrument must be tested. The study will use the two most common types of validity, which are content and construct validity. While content validity will be tested through the expert contributions from my supervisors, construct validity will be tested with the use of factor analytical tool that considered Kaiser-Meyer-Olkin (KMO) and Bartlett's Test of Sphericity among others. To establish the reliability and validity of the instrument, the pilot test technique was carried out using $30 \%$ of the total sample of the study while Cronbach Alpha Coefficient will be used in estimating the reliability of the instrument. 
Table 1: Kaiser-Meyer-Olkin and Bartlett's test

\section{KMO and Bartlett's Test}

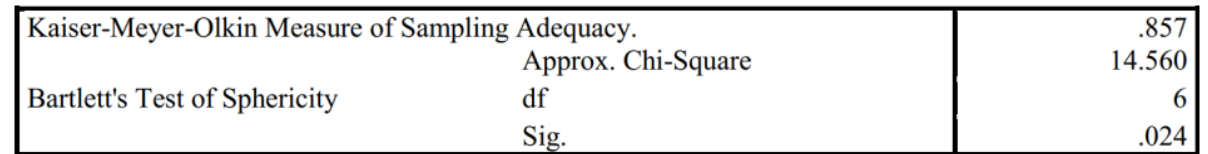

Source: SPSS Result, 2019

After the pilot test was conducted, the input variable factors used for this study were subjected to exploratory factor analysis to investigate whether the constructs as described in the literature fits the factors derived from the factor analysis. Factor analysis indicates that the KMO (Kaiser-Meyer-Olkin) measure for the study's two independent variable items is 0.857 with Barlett's Test of Sphericity (BTS) value to be 6 degrees of freedom at a level of significance $\mathrm{p}=0.024$.

Our KMO result in this analysis surpasses the threshold value of 0.50 as recommended by Hair, Anderson, Tatham, and Black (1995). Therefore, we are confident that our sample and data are adequate for this study.

\section{Table 2: Total Variance Explained}

Total Variance Explained

\begin{tabular}{|l|r|r|r|r|r|r|r|r|r|}
\hline \multirow{2}{*}{$\begin{array}{l}\text { Compo } \\
\text { nent }\end{array}$} & \multicolumn{3}{|c|}{ Initial Eigenvalues } & \multicolumn{3}{|c|}{$\begin{array}{c}\text { Extraction Sums of Squared } \\
\text { Loadings }\end{array}$} & \multicolumn{3}{|c|}{ Rotation Sums of Squared } \\
\cline { 2 - 9 } & Total & $\begin{array}{c}\% \text { of } \\
\text { Variance }\end{array}$ & $\begin{array}{c}\text { Cumulati } \\
\text { ve } \%\end{array}$ & Total & $\begin{array}{c}\text { \% of } \\
\text { Variance }\end{array}$ & $\begin{array}{c}\text { Cumulati } \\
\text { ve } \%\end{array}$ & Total & $\begin{array}{c}\% \text { of } \\
\text { Variance }\end{array}$ & $\begin{array}{c}\text { Cumulati } \\
\text { ve \% }\end{array}$ \\
\hline 1 & 2.016 & 50.405 & 50.405 & 2.016 & 50.405 & 50.405 & 1.733 & 43.330 & 43.330 \\
2 & 1.023 & 25.571 & 75.977 & 1.023 & 25.571 & 75.977 & 1.306 & 32.647 & 75.977 \\
3 & .644 & 16.094 & 92.071 & & & & & & \\
4 & .317 & 7.929 & 100.000 & & & & & & \\
\hline
\end{tabular}

Extraction Method: Principal Component Analysis.

Source: SPSS Result, 2019

As shown in Table 2 on the column of the rotation sum of squared loadings section, two components i.e. component 1 and 2 accounted for $75.977 \%$ of the variance of the whole variables of the study. This shows that the variables have strong construct validity.

This is the consistency between independent measurements of the same phenomenon. It is the stability, dependability and predictability of a measuring instrument. It is also the accuracy or precision of a measuring instrument.

\section{Reliability of Instrument \\ Table 3: Reliability Statistics}

\section{Reliability Statistics}

\begin{tabular}{|l|l|l|}
\hline Cronbach's Alpha & $\begin{array}{l}\text { Cronbach's Alpha Based on } \\
\text { Standardized Items }\end{array}$ & N of Items \\
\cline { 1 - 2 } .875 & .961 & 4 \\
\hline
\end{tabular}

\section{Source: SPSS Result, 2019}

Table 3 shows the reliability statistics which indicates that the Cronbach Alpha value is 0.875. Reliability Cronbach Alpha statistics of 0.70 is considered adequate and reliable for study. Hence, the variable of this study falls above the limit of a reliable instrument for research study.

\section{Model Specification}

Guided by the functional relationship between the variables of the study the following implicit and explicit relationship exists between the variables of the study. The implicit relationship is shown as follows for model 1 to 4 :
$\mathrm{JOC}=f(\mathrm{CMF})-$
$\mathrm{BEX}=f(\mathrm{CMF})$
$\mathrm{JOC}=f(\mathrm{SMB})-$
$\mathrm{BEX}=f(\mathrm{SMB})$
Where,
JOC $=$ Job Creation
$\mathrm{BEX},=$ Business Expansion
$\mathrm{CMF}=$ Credit by Microfinance Bank
$\mathrm{SMB}=$ Savings Mobilization

(1)

The explicit relationship between the variables of the study is as shown below:

$\mathrm{JOC}=\mathrm{b}_{0}+\mathrm{b}_{1} \mathrm{CMF}+\mathrm{U}_{\mathrm{t}}$

$\mathrm{BEX}=\mathrm{b}_{0}+\mathrm{b}_{1} \mathrm{CMF}+\mathrm{U}_{\mathrm{t}}$ 
$\mathrm{JOC}=\mathrm{b}_{0}+\mathrm{b}_{1} \mathrm{SMB}+\mathrm{U}_{\mathrm{t}}$

$\mathrm{BEX}=\mathrm{b}_{0}+\mathrm{b}_{1} \mathrm{SMB}+\mathrm{U}_{\mathrm{t}}$

Where,

$\mathrm{b}_{0}=$ Regression Intercept or Slope

$\mathrm{b}_{1}=$ Regression Coefficient

$\mathrm{U}_{\mathrm{t}}=$ Error or Stochastic Term

\section{A priori expectations}

$\left(\boldsymbol{X}_{\mathbf{1}}\right)=$ Credit by Microfinance Bank; $a$ priori expectation is positive

$\left(\boldsymbol{X}_{2}\right)=$ Savings Mobilization; $a$ priori expectation is positive

\section{Methods of Data Analysis}

The data for the study was collected, coded and analyzed using computer-based Statistical Package for Social Sciences (SPSS version 20 for Microsoft Windows). Various statistical methods were used in analyzing this study: percentages, frequency and tables were used to examine the respondents' bio-data.

Multiple regression analysis was used to assess the nature and degree of relationship between the dependent variable and a set of independent or predictor variables. Simple Linear regression analysis was used to examine the effect of the independent variables of the study on the dependent variables of the study. However, standard error of the estimate was used to test the 4 hypotheses for this study.

Decision rule: The following decision rules were adopted for accepting or rejecting hypotheses: If the probability value of $b_{i}\left[p\left(\mathrm{~b}_{\mathrm{i}}\right)>\right.$ critical value] we accept the null hypothesis, that is, we accept that the estimate $b_{i}$ is not statistically significant at the $5 \%$ level of significance.

If the probability value of $b_{i}\left[p\left(\mathrm{~b}_{\mathrm{i}}\right)<\right.$ critical value $]$ we reject the null hypothesis, in other words, that is, we accept that the estimate $b_{1}$ is statistically significant at the $5 \%$ level of significance.

\subsection{RESULTS AND DISCUSSION}

Table 4: Regression coefficients

\begin{tabular}{|l|l|l|l|l|}
\hline Model & Variables & Beta & t-test & Sig level \\
\hline JOC & CMF & .409 & 1.901 & .034 \\
\hline BEX & CMF & .317 & 1.417 & 0.017 \\
\hline JOC & SMB & -0124 & -0.532 & 0.601 \\
\hline BEX & SMB & 0.393 & 1.814 & 0.029 \\
\hline
\end{tabular}

Source: SPSS Result, 2019

A positive relationship exist between Credit by Microfinance (CMF) and the Growth of Small and Medium Scale Enterprises proxied by Job Creation (JOC) by selected SMEs in Makurdi Metropolis and the relationship is statistically significant $(p<0.05)$ and in line with a priori expectation. This means that a unit increases in Credit by Microfinance (CMF) will result to a corresponding increase in Growth of Small and Medium Scale Enterprises proxied by Job Creation (JOC) by a margin of $40.9 \%$. Using the probability value of the estimate, $p\left(b_{1}\right)<$ critical value of 0.05 confidence level. Thus, we reject the null hypothesis. That is, we accept that the estimate $b_{1}$ is statistically significant at the $5 \%$ level of significance. This implies that credits by microfinance banks has a significant effect on job creation by selected SMEs in Makurdi Metropolis.

This finding is in line with that of Ojo (2009) who investigated the impact of microfinance on entrepreneurial development of small scale enterprises that are craving for growth and development in a stiffened economy of Nigeria and found that there is a significant effect of microfinance institutions activities in predicting entrepreneurial productivity thus creating jobs for the countless number of entrepreneurs. The study concludes that microfinance institutions world over and especially in Nigeria are identified to be one of the key players in the financial industry that have positively affected individuals, business organizations, other financial institutions, the government and the economy at large through the services they offer and the functions they perform in the economy.

As shown by the result of the regression analysis, a positive relationship exist between Credit by Microfinance and the Growth of Small and Medium Scale Enterprises proxied by Business Expansion (BEX) by selected SMEs in Makurdi Metropolis and the relationship is statistically significant $(p<0.05)$ and in line with a priori expectation. This means that a unit increases in Credit by Microfinance (CMF) will result to a corresponding increase in Growth of Small and Medium Scale Enterprises proxied by Business Expansion (BEX) of selected SMEs in Makurdi Metropolis by a margin of $31.7 \%$. Using the probability value of the estimate, $p\left(b_{1}\right)<$ critical value of 0.05 confidence level. Thus, we reject the null hypothesis. That is, we accept that the estimate $b_{1}$ is statistically significant at the $5 \%$ level of significance.

This implies that Credit by microfinance has a significant on business expansion of selected SMEs in Makurdi Metropolis. This finding is in tandem with that of Babajide (2011) who investigated the effects of micro-financing on Micro and Small Enterprises (MSEs) in South-west Nigeria. The study found that micro finance and micro-financing enhance survival of Micro and Small Enterprises (MSEs) and sufficient for growth and expansion of such Micro and Small Enterprises. The result also revealed that microfinance has positive effects on productivity and performance of local entrepreneurs. 
A negative relationship exist between Savings Mobilization and the Growth of Small and Medium Scale Enterprises proxied by Job Creation (JOC) by selected SMEs in Makurdi Metropolis and the relationship is not statistically significant $(p>0.05)$ and is not in line with a priori expectation. This means that a unit increases in Savings Mobilization (SMB) will result to a corresponding decrease in Growth of Small and Medium Scale Enterprises proxied by Job Creation (JOC) of selected SMEs in Makurdi Metropolis by a margin of $12.4 \%$. Using the probability value of the estimate, $p\left(b_{1}\right)>c r i t i c a l$ value of 0.05 confidence level. Thus, we accept the null hypothesis. That is, we accept that the estimate $b_{1}$ is not statistically significant at the $5 \%$ level of significance. This implies that Savings mobilization by Microfinance has no significant effect on job creation by selected SMEs in Makurdi Metropolis.

The study Sambe, Korna and Abaniyan (2013) on the effect of microfinance institutions on socio-economic development in Nigeria found similar result. The finding indicates that The study made use of randomly sampled 200 respondents as questionnaires. Chi-square was employed in the test of hypotheses. Dependency theory was used in analyzing the study. Findings showed that Informal Microfinance Institutions were more effective in improving job creation through the volumes of savings they mobilize from the various businesses in the rural area. These savings are loaned to entrepreneurs who use them or business expansion thus reducing poverty among members than non-members. Furthermore, the institutions guaranteed more access to credit than nonmembers and lastly, Informal Financial Institutions were effective in promoting investment among members as compared to non-members.

A positive relationship exist between Savings Mobilization (SMB) and the Growth of Small and Medium Scale Enterprises proxied by Business Expansion (BEX) by selected SMEs in Makurdi Metropolis and the relationship is statistically significant $(p<0.05)$ and in line with a priori expectation. This means that a unit increases in Savings Mobilization (SMB) will result to a corresponding increase in Growth of Small and Medium Scale Enterprises proxied by Business Expansion (BEX) by a margin of $40.9 \%$. Using the probability value of the estimate, $p\left(b_{1}\right)<$ critical value of 0.05 confidence level. Thus, we reject the null hypothesis. That is, we accept that the estimate $b_{1}$ is statistically significant at the $5 \%$ level of significance. This implies that Savings mobilization by microfinance has a significant effect on business expansion of selected SMEs in Makurdi Metropolis.

The finding is in line with that of Ndugbu, Ojiegbe, Lawrence and Okere (2015) who examined the relationship between bank and non-bank financial institutions and the development of the Nigerian economy. The study as confirmed by the result of the joint test revealed that the financial institutions from their intermediary functions plays prominent role on the growth and development of the small and medium scale enterprises and the Nigerian economy at large.

\subsection{CONCLUSION AND RECOMMENDATIONS}

\section{Conclusion}

This study examined the Effect of Microfinance Banks on the Growth of selected Small and Medium Scale Enterprises in Makurdi Metropolis, Benue State. The main findings of this research revealed that micro-financing as practiced in Nigeria microfinance banks do enhance growth such as the SMEs' capacity to create jobs and increase their expansion capacity. Lack of access to finance has been identified as one of the major constraints to small business growth. The reason is that provision of financial services has been identified as an important means for mobilizing resources for more productive use. The extent to which small enterprises could access fund is the extents to which small firms can save and accumulate own capital for further investment. However, it has been identified that small business enterprises in Nigeria find it difficult to access formal financial institutions such as commercial banks for funds. The inability of the SMEs to meet the standard of the formal financial institutions for loan consideration provides a platform for informal institutions to attempt to fill the gap usually based on informal social networks, and this is what gave birth to micro-financing.

The significant position of the overall fstatistic led to our decision to reject the null hypothesis for the three samples, which implies that micro finance does enhance the job creation and expansion capacity of small business in Nigeria. Looking at the result critically, it was also revealed that among small firm sample, variables such as credit by microfinance banks and savings mobilizations are the variables that impact significantly on small business growth.

\section{Recommendations}

The following recommendations are made based on the findings of this study. They are as follow:

1. To access more credit for business expansion enterprise supported by MFBs should be linked up with larger financing window like the Small and Medium Enterprise Equity Investment Scheme (SMEEIS) fund or Strategic Partners for expansion and growth fund for business growth and survival. The entrepreneurs could also be linked up with other commercial banks who will service the entrepreneurs through the MFBs based on social capital.

2. This study suggests that policies aimed at promoting the growth of micro and small enterprises should adopt a sectoral approach and, within that, address specific issues that affect enterprises at the lower and upper ends of the spectrum of growth and expansion.

3. It is recommended that the microfinance bank should adopt similar strategies adopted by deposit money banks in deposit mobilization because it is by so doing that they will be able to grant quality loans to entrepreneurs which will lead to job creation in the economy.

4. Since the expansion of the small and medium scale enterprises is linked to the amount of loan obtained by the SMEs, management of the microfinance in the study area should give preference to sourcing of partnership in the granting of loans to the entrepreneurs so that the microfinance banks can raise enough revenue in financing the activities of the entrepreneurs in the study area. 


\section{REFERENCES}

[1].Abdesselam R, Bonnet J, and Le Pape, N. (2014). An Explanation of the Life Span of New French Enterprises. Small Bus. Econ., 23: 237-254.

[2].Abiola, I., \& Salami, A.O. (2011). Impact of Microfinance Banks on Standard of Living. International Journal of Business Management, 5(1):27-32.

[3].Acha, I. A. (2012). Microfinance Banking in Nigeria: Problems and Prospects. International Journal of Finance and Accounting, 1(5), 106-111.

[4].Aderibigbe, J. O. (2001). The Role of the Federal Sector in Poverty Reduction, Central Bank of Nigeria Bullion, 39(4), $13-24$.

[5].Arbaurgh, J.B., \& Sexton, D.L. (1996). New Firm Growth and Development: A Replication and Extension of Reynolds' research. Journal of Enterprising Culture, 4(1):19-36

[6].Babajide, A. A. (2011). Effects of Micro financing on Micro and Small Enterprises (MSEs) in South West in Nigeria. Being a PhD Thesis submitted in Partial Fulfillment of the Requirements for the Award of PhD Banking and Finance of the Department of Banking and Finance, College of development Studies, Covenant University, Ota, Nigeria.

[7].Bello, A. R. (2015). Empire Trust Microfinance Bank: Lagos. The Punch, p. 1.

[8].Berger, A. N. \& Udell, G. F. (1998). A More Complete Conceptual Framework for SME Finance. In: Small and Medium Enterprises: Overcoming Growth Constraints World Bank, MC13-121, October 14-15.

[9].Brüderl J, Preisendörfer P, Ziegler R (2012). Survival Chances of Newly Founded Business Organizations. Am. Sociol. Rev., 57: 227-242.

[10].CBN (2014). Understanding Monetary Policy Series No.43: The Informal Financial Market inNigeria.www.cbn.gov.ng retrieved $31^{\text {st }}$ July, 2017.

[11]. Central Bank of Nigeria (2005).Guidelines and Procedures for the Establishment of Microfinance Banks in Nigeria. CBN Bullion, 2005.

[12]. Chaston, I. and Mangles, T. (2017), Competencies for growth in SME sector manufacturing firms, Journal of Small Business Management, 35(1):32-41.

[13]. Chittenden, F., Hall G. and Hutchinson, P. (1996). Small firm growth, access to capital markets and financial structure: Review of issues and an empirical investigation. Small Business Econ., 8: 59-67.

[14]. Ediomo-Ubong E. Nelson and IboroEkpo Nelson (2010). Micro-Credit Programme and Poverty Alleviation in Rural Nigeria: A Case Study of Akwa Ibom State. International Journal of Economic Development Research and Investment, vol. 1 nos. $2 \& 3$ 2010. Retrieved $10^{\text {th }}$ June, 2017.

[15]. Ehigiamusoe, G. (2016). Risk management in microfinance. Paper presented at a Workshop Organized by the CBN for Directors of Potential Microfinance Banks, CBN Owerri, 17-19 August, 2006.

[16]. Esteve-Pérez, S. and Mañez-Castillejo, J. A. (2008). The resource-based theory of the firm and firm survival. Small Business Economic. 30(1): 231-249.

[17]. Goffee, R. and Scase, R., (2015). Entrepreneurship in Europe (Routledge Revivals): The Social Processes. Routledge Hair, J. F., Anderson, R. E., Tatham, R. L., \& Black, W. C. (1995). Multivariate Data Analysis. Englewood Cliffs, NJ: Prentice-Hall.

[18]. Hall, G.C., P.J. Hutchinson and N. Michaelas, 2004. Determinants of the capital structures of European SMEs. Journal of Business Finance and Accounting, 31: 711728.

[19]. Hannan, M. T. (2018). Rethinking age dependence in organizational mortality: logical formulizations. American Journal of Social Sociology, 104(2), 126-164.

[20]. Holmes, S. and Kent, P. (1991). An empirical analysis of the financial structure of small and large Australian manufacturing enterprises. Journal of Small Business Finance, 1: 141-154

[21]. Idowu, A. O, Ambali O. I. and Otunaiya A. O. (2010). Microfinance and Small Scale Pig Business in Osun State, Nigeria.

[22]. Asian Journal of Business and Management Sciences 1(9):01-08. www.ajbms.org. Accessed 10 ${ }^{\text {th }}$ July, 2018.

[23]. Iganiga, B. O. and Asemota, A. (2008). The Nigerian Unorganized Rural Financial Institutions and Operations: A Framework for Improved Rural Credit Schemes in a Fragile Environment. Journal of Social Sciences, 17(1): 63-71.

[24]. Ketu, A. A. (2008). Microfinance Banks in Nigeria: An Engine for Rural Transformation "West African Institute for Financial and Economic Management. Lagos, Nigeria.

[25]. Kolvereid, L. (2016). Growth Aspirations among Norwegian Entrepreneurs. Journal of Business Venturing, 7(3):209-222.

[26]. Kolvereid, L. and Bullvag, E. (2016). Growth Intentions and Actual Growth: The Impact of Entrepreneurial Choice. Journal of Enterprising Culture (JEC), 4(1):1-17

[27]. Kpelai, S.T. (2010). Financing Options and Constraints to Small Businesses in Benue State North-Central Nigeria. Mkar Journal of Management and Social Sciences 2(1), 1-12.

[28]. Lv, G. S. (2000). Small and Medium Enterprises Research. Shanghai: Shanghai University of Finance and Economics Press. (In Chinese).

[29]. Masurel, E. and Montfort, K.V. (2016). Life cycle characteristics of small professional service firms. Journal of Small Business Management, 44(3):461- 437 Myers, S.C., (1984). The capital structure puzzle. Journal of Finance, 39(3): 575-592.

[30]. Ndugbu, J. O., Ojiegbe, M., Lawrence, K. and Okere, M. J. (2015). Innovative approach to SME financing in Nigeria: a review of small and medium industries equity investment scheme (SMIEIS). Journal of Social Science, 11(3):219-227. 
[31]. Ngozi, G. I (2012). Women Entrepreneurship and Development: The Genering of Microfinance in Nigeria. Presented at the $8^{\text {th }}$ International Interdisciplinary Congress on Women, 21-26 July, 2002, Makerere University, Kampala-Uganda.

[32]. Ojo, T.A. (2009). A study of the Role of Banking and Financing Institutions and Markets in Development Economy. London: Graham Burn Romano, C. O., Tanewiski, G. A. and Smyrnios, K. X. (2001). Capital Structure Decision Making: A Model for Family Business. Journal of Business Venturing, 16(3):285310.

[33]. Sambe, L., Korna H. and Abaniyan, P. (2013). The Experience of Microfinance Banks Operation in their operational location. Paper presentation at workshop on microfinance banking in Kano State.

[34]. SMEDAN (2017), Survey Report on Micro, Small and Medium Enterprises (MSMEs) in Nigeria USAID (2015). USAID Fiscal Year 2015 Agency Financial Report. Online @ https://www.usaid.gov/sites/default/ files/documents/1868/USAIDFY20 15AFR_508a.pdf

[35]. Wucinich, W. (2009). How to Finance a Small Business. Journal of Management Accounting, 61(5):1618. 